\title{
Retrieval of Fractured Screws from Dental Implants - A Case Report
}

\author{
Nischal $\mathbf{K}^{1 *}$ and Chowdhary $\mathbf{R}^{2}$ \\ ${ }^{1}$ Researcher, Department of Prosthodontics, Rajarajeswari Dental College and Hospital, India
}

${ }^{2}$ Professor, Department of Prosthodontics, Rajarajeswari Dental College and Hospital, India

Submission: November 15, 2017; Published: April 26, 2018

*Corresponding author: Kunal Nischal, Department of Prosthodontics, Rajarajeswari dental college and hospital, Bengaluru-560074, India, Email: drkunal1001@gmail.com

\begin{abstract}
Introduction of dental implant to prosthetic dentistry has provided an alternative to rehabilitate edentulous patients. Rehabilitation with implants is nowadays considered a predictable solution, with increased success rates. However, biological and technical complications are frequent.
\end{abstract}

Keywords: Hybrid; Framework; Screw; Fracture; Retrieval

\section{Introduction}

Implant therapy is a very effective and reliable method involved in the treatment of complete or partial edentulism [1]. The success of dental implant treatment depends on biological and mechanical factors. Biologically the success of dental implant depends on the long term osseointegration which is sensitive to atraumatic implant placement and restoration [2]. This type of prosthesis significantly improves the quality of life of the edentulous patients as compared to conventional compete denture patients, since they offer functional, aesthetical and psychological advantages [3]. Nevertheless a series of mechanical complications had been registered with the employment of this type of prosthesis [4].

Sekine et al. [5] in a study found that a mobility range of 17 to 58 microns labially and 17 to 66 microns lingually for osseointegrated implants with load of upto $2000 \mathrm{~g}$, results in bone deformation. This is in contrast to 100 and 200 microns range associated with periodontal ligament [5]. Because of less movement of the implant the precision of cast framework would be more crucial with fixed prosthesis when connected to dental implants [6]. Mechanically the success depends on the implant, its components (transmucosal abutment and abutment screw), prosthesis (prosthetic screw). One of the most common mechanical complications include screw loosening (abutment or prosthetic), screw fracture and problems with overdenture attachments [7].

Implant abutment connections plays a significant role in complication of screw loosening. An implant having a short $(<2 \mathrm{~mm})$ external hex at the prospective connection with the abutment seems to be especially prone to screw loosening as compared to internal taper/conical implant abutment connection with anti-rotational feature [8]. A high incidence of screw loosening of upto $40 \%$ was found for external hex connection as reported by Becker $\mathrm{W}$ and Becker BE [9]. In contrast, Levine et al reported lower rate of abutment screw loosening of about 3.6\%-5.3\% with conical implant-abutment connections, restoring single-tooth replacements with cemented crowns $[10,11]$.

\section{Case Report}

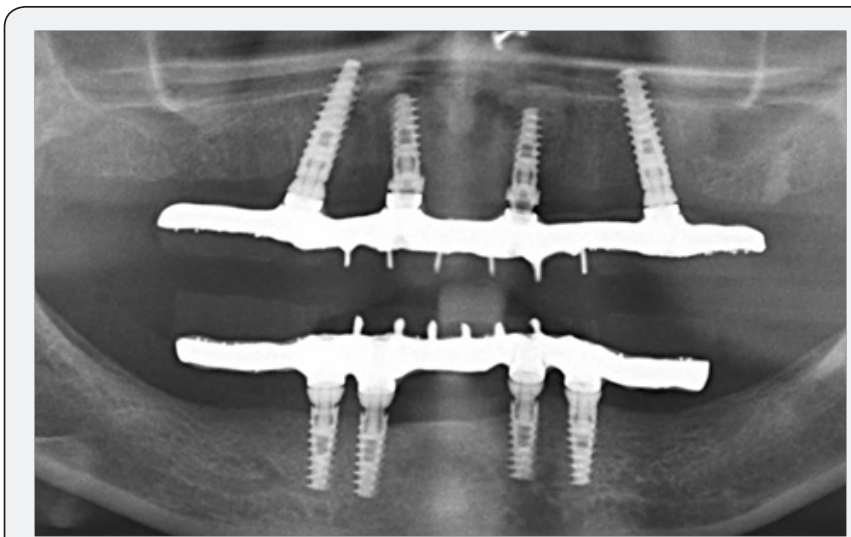

Figure 1: Pre-operative orthopantomograph showing non passive frameworks.

A 65 years old lady reported, with a chief complaint of loose upper and lower hybrid dentures. Earlier history revealed that, she was treated one year back with All-on-four concept of implants in both maxillary and mandibular edentulous arch for 


\section{Advances in Dentistry \& Oral Health}

hybrid prosthesis. After around 7 months of restoration, patient came back to the department, with loosening of the maxillary and mandibular prosthesis. Clinical and radio-graphical examination revealed fractured prosthetic screw in three multiunit abutments, in region of 22, 32, 42 and the frameworks were not passively seated (Figure 1-3). After explaining the situation to the patient, it was decided to remove the broken screws and replaced with newer prosthetic screws with complete new hybrid prosthesis as the casted frameworks were not passive.

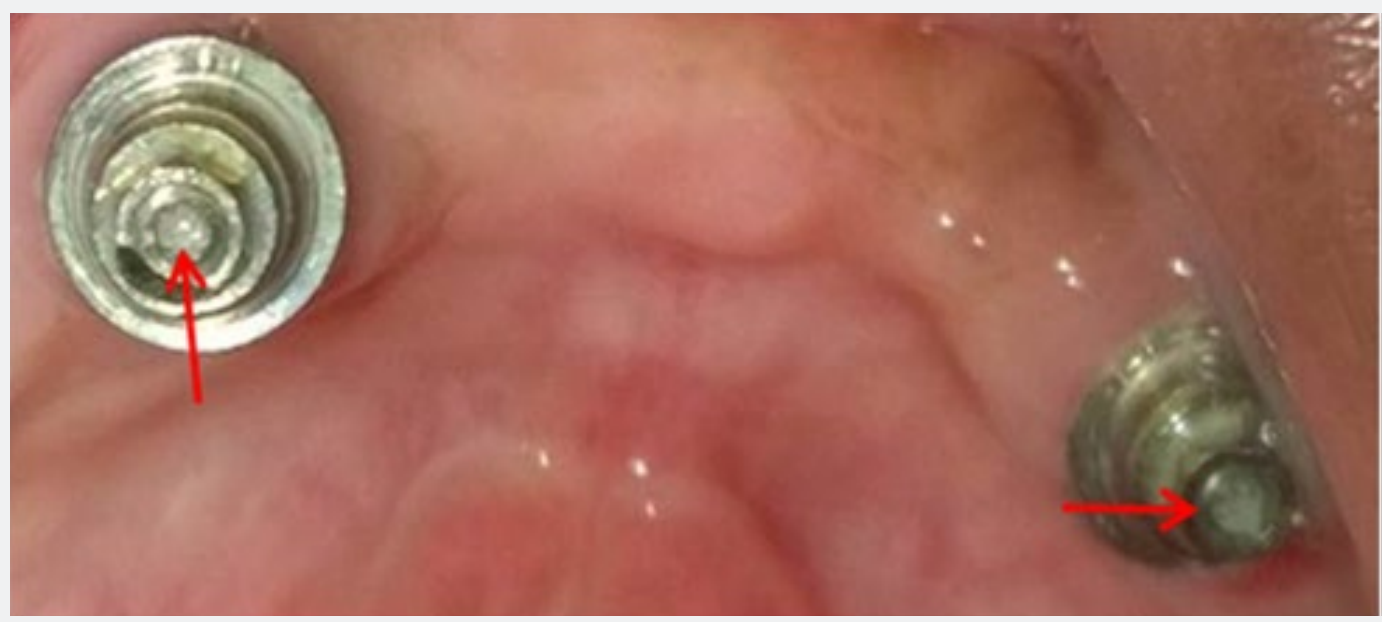

Figure 2: Broken screws in muti-unit abutments in 32 and 42 regions.

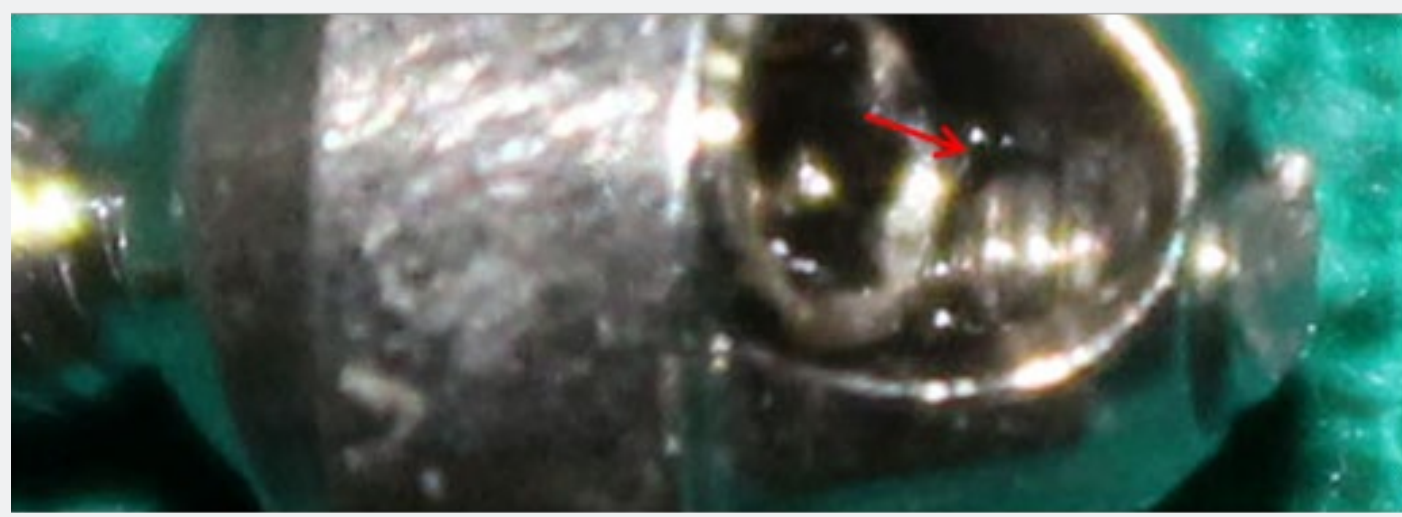

Figure 3: Broken screw inside multi-unit abutment in 22 region.

\section{Procedure of removal}

a) The multiunit abutments with broken screws were retrieved from the implants by engaging the external hex of the straight multiunit abutment.

b) Under magnifying glass with a needle diamond bur (No. 101, Shofu INC, Kyoto, Japan) of air rotor (NSK, Ti-Max Z900 L, Tokyo, Japan) without water spray for proper visibility a fissure was created on the head of the broken screws.

c) A modified spoon excavator (ESC 820, GDC, INDIA) was used as a screw driver, which was engaged in the fissure created and rotated anti- clockwise to remove the broken screws (Figure 4-6).

d) New both maxillary and mandibular hybrid prosthesis were then fabricated as the frameworks were not passive (Figure 7). Post prosthesis oral pantomograph showed a passively seated hybrid prosthesis framework (Figure 8). e) Patient was followed up for 2 years, every 6 months. No further complication occurred during the follow up period.

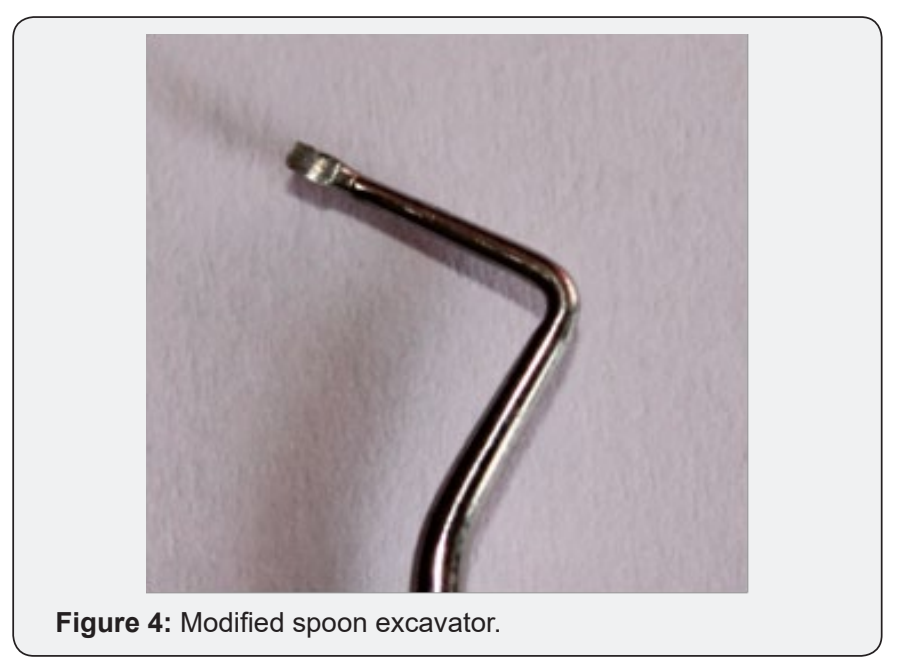




\section{Advances in Dentistry \& Oral Health}

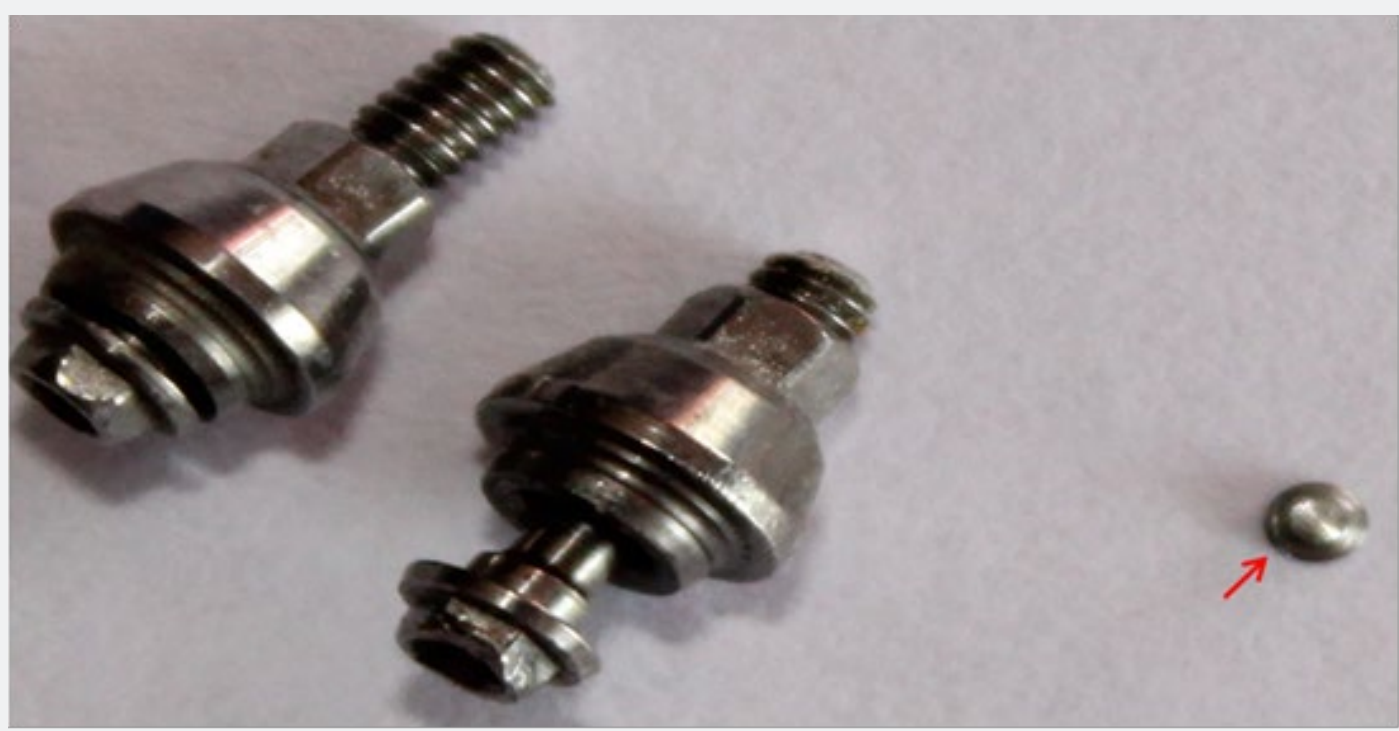

Figure 5: Broken screws retrieved from the multi-unit abutment in 32 and 42 region.

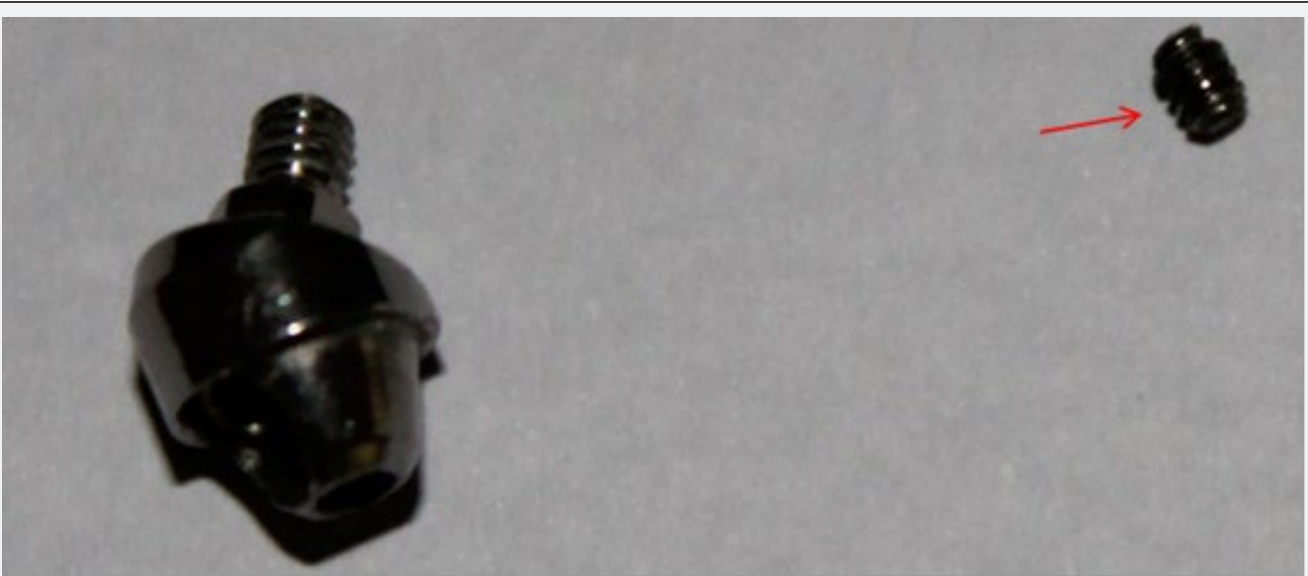

Figure 6: Broken screw retrieval from multiunit abutment in 22 region.

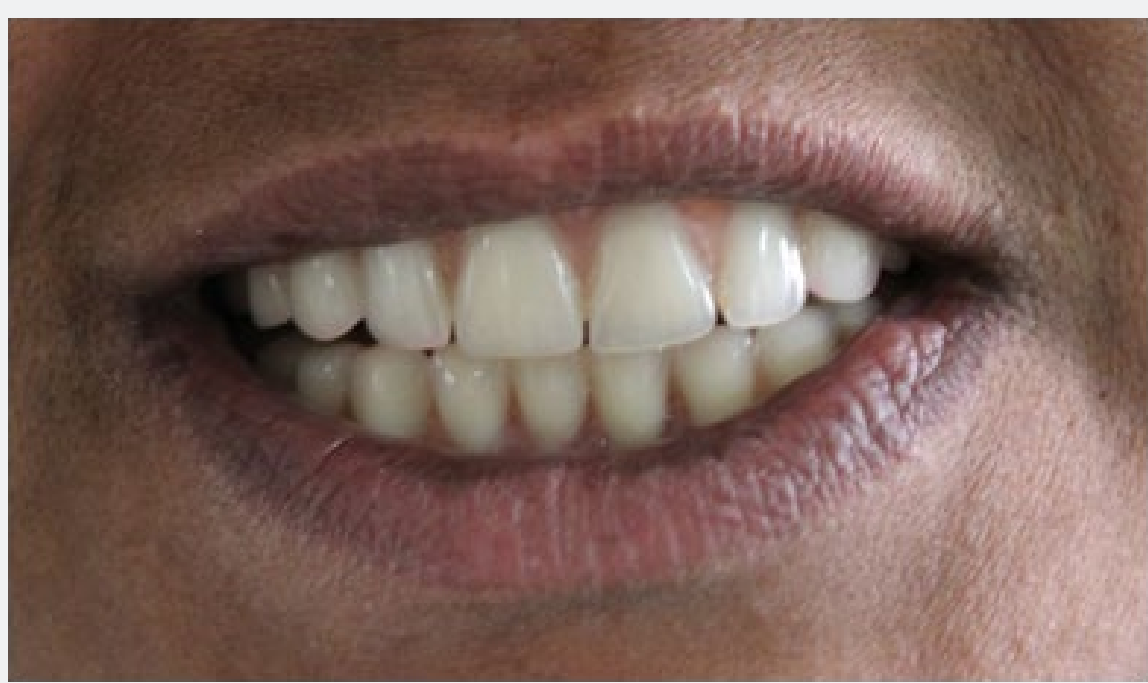

Figure 7: New complete hybrid prosthesis. 


\section{Advances in Dentistry \& Oral Health}

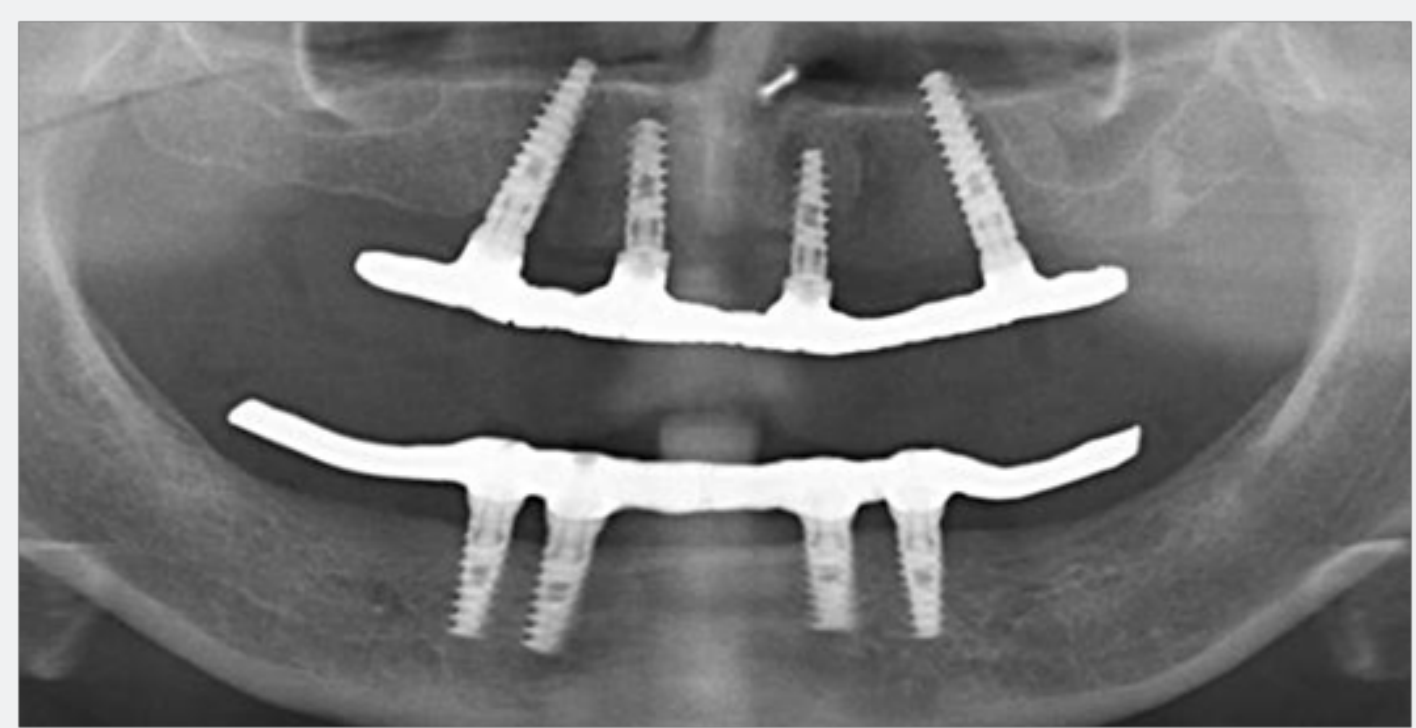

Figure 8: New complete hybrid prosthesis

\section{Discussion}

The desirability of "passive fit" of implant prosthesis is generally recognised, as it is considered as the "holy grail of the discerning implant prosthodontists" $[12,13]$. The concept of passive fit remains controversial and has been understood partially [14]. Although failure to eliminate distortion between the frameworks and implant abutments has been one of the reason for biologic complication or delayed component failure [15]. Therefore misfit in case of implant supported prosthesis will be more destructive and this misfit can lead to serious screw joint complications. Screw-joint involves a number of critical factors such as, adequate preload, precision fit of implant components and basis antirotational characteristics of implant to abutment connection [16]. Torqueing of an abutment has a clamping effect, called the preload which causes elongation of the screw [17]. The clamping force is directly proportional to the force used to tighten the screw. The suggested amount of the torque for a preload should be $75 \%$ of the value to reach permanent deformation to provide a safety value for the screw joint [18]. The most common causes of screw loosening and fracture have been categorised as inadequate tightening, adverse occlusal forces and fatigue character and yielding strength of the screw material $[19,20]$. Moreover, the surface of new metal screw has surface imperfections in the form of high spots, grooves and irregularities, such that when initial load is applied only the high spots on the screw will be in contact. Flattening and wear of these high spots is described as settling of screw and which results in loss of some initial preload [21]. Binon [22] suggested that a mean flat to flat range of less than $0.005 \mathrm{~mm}$ on the same hexagon and a flat to flat range of less than $0.05 \mathrm{~mm}$ for the entire sample results in a more stable screw joint [22]. The relationship between torque and preload is not linear [23]. Friction should also be considered in the system. Approximately $90 \%$ of the applied torque is lost as friction. Depending on manufacturer and system recommended torque values range between 20 to $35 \mathrm{Ncm}$ and a torque wrench is required to obtain a more consistent value [24]. However a screw is tightened until plastic deformation takes place and loss of preload occurs with possibility of screw loosening and fracture. The stability of implant abutment connection is influenced by factors such as internal /external connection, screw head design, screw geometry, materials, screw diameter and overall screw mechanics. Relative to external hexagon internal implant abutment connection shows higher stability and improved force distribution [25]. To maximise the preload and minimize the loss of input torque to friction, the head of the screw should be wider than the thread diameter of the screw [26]. The head most often should be flat to dissipate stresses more evenly within the threads and head of the screw [26]. These screws are of either gold or titanium or gold-coated titanium with the tensile and yield strengths being highest for gold screws $[27,28]$. The major disadvantage of titanium screws is their tendency to cause galling, which results in excessive friction between the two mating surfaces thereby causing localised welding with a further roughening of mating surfaces [29]. Galling occurs in the following manner. Ttanium of the retaining screws slide in contact with the titanium of the implant body, the coefficient of friction increases whereby titanium molecules transfer from the mating surfaces [30]. This has been described as adhesive wear mechanism which causes damage to both implant and screw threads [31]. Screw fracture and loosening are closely linked. It has been suggested that screw loosening is the initial stage of screw fracture [32]. When a screw loosens damage occurs at high stress locations like screw heads and first thread. Consequently loose abutment screw should always be replaced as a loose screw could have a fatigue history predisposing it to fracture [16]. Williams in a study reported that hydrogen at concentrations as low as $200 \mathrm{ppm}$ (by mass) can cause marked reduction in ductility of titanium and plastic deformation of the screw can accelerate absorption of hydrogen which makes screws vulnerable to fracture $[33,34]$. 
This case demonstrates the need to consider all possibilities when faced with abutment screw loosening or fracture and further highlights the need for multidisciplinary skills in the treatment of patients with implants.

\section{Competing Interest}

No conflicts of interest.

\section{Author's Contribution Section}

KN carried out the original case study and RC participated in sequence alignment.

\section{Consent of the Patient}

"Consent, for the publication of this case report and any additional related information was taken from the patient involved in the study".

\section{References}

1. Adell R, Eriksson B, Lekholm U, Branemark PI, Jemt T (1990) Longterm follow-up study of osseointegrated implants in the treatment of totally edentulous jaws. Int J Oral Maxillofac Implants 5(4): 347-359.

2. Adell R, Lekholm U, Rockler B, Branemark PI (1981) A 15-year study of osseointegrated implants in the treatment of the edentulous jaw. Int $\mathrm{J}$ Oral Surg 10(6): 387-416.

3. Meijer HJ, Raghoebar GM, Van't Hof MA (2003) Comparison of implantretained mandibular over-dentures and conventional complete dentures: a 10-year prospective study of clinical aspects and patient satisfaction. Int J Oral Maxillofac Implants 18(6): 879-885.

4. Ekelund JA, Lindquist LW, Carlsson GE, Jemt T (2003) Implant treatment in the edentulous mandible: a prospective study on Brånemark system implants over more than 20 years. Int J Prosthodont 16(6): 602-608.

5. Sekine H, Komiyoma Y, Hotta H, Yoshida K (1985) Mobility characterstics and tactile sensitivity of osseointegrated fixture system. In: Van Steenbergle D (Ed.), Tissue integration in oral and maxillofacial reconstruction. Proceedings of an international congress, Elsevier science publishers, Brussels. Amsterdam, USA.

6. Jemt T, Lie A (1995) Accuracy if of implant supported prosthesis in the edentulous jaw: analysis of precision of fit between the gold-alloy frameworks and mastercasts by means of a 3D photogrammetric technique. Clin Oral Implants Res 6(3): 172-180.

7. Goodacre CJ, Kan JY, Rungcharassaeng K (1999) Clinical complications of osseointegrated implants. J Prosthet Dent 81(5): 537-552.

8. Merz BR, Hunenbart S, Belser UC (2000) Mechanics of the implantabutment connection: an 8-degree taper compared to a butt joint connection. Int J Oral Maxillofac Implants 15(4): 519-526.

9. Becker W, Becker BE (1995) Replacement of maxillary and mandibular molars with single endosseous implant restorations: A retrospective study. J Prosthet Dent 74: 51-55.

10. Levine RA, Clem DS, Wilson TG Jr, Higginbottom F, Saunders SL (1999) A multicenter retrospective analysis of the ITI implant system used for single-tooth replacements: Results of loading for 2 or more years. Int $]$ Oral Maxillofac Implants 14(4): 516-520.

11. Levine RA, Clem DS, Wilson TG Jr, Higginbottom F, Solnit G (1997) Multicenter retrospective analysis of the ITI implant system used for single-tooth replacements: Preliminary results at 6 or more months of loading. Int J Oral Maxillofac Implants 12(2): 237-242.

12. Carlsson L (1994) Built-in strain and untoward forces are the inevitable companions of prosthetic misfit. Nobelpharma News 8: 5 .
13. Tan KB (1995) The clinical significance of distortion in implant prosthodontics: Is there such a thing as passive fit? Ann Acad Med Singapore 24(1): 138-157.

14. Wee AG, Aquilino SA, Schneider RL (1999) Strategies to achieve fit in implant prosthodontics: a review of the literature. Int J Prosthodont 12(2): 167-178.

15. Fusayama T, Wakumoto S, Hosada H (1964) Accuracy of fixed partial dentures made by various soldering techniques and one-piece castings. J Prosthet Dent 14(2): 334-342.

16. Schwarz MS (2000) Mechanical complications of dental implants. Clin Oral Implants Res 11( Suppl 1): 156-158.

17. Haack JE, Sakaguchi RL, Sung T, Coffey JP (1995) Elongation and pre load stress in dental abutment screws. Int J Oral Maxillofac Implants 10(5): 529-536.

18. Jorneus L, Jemt T, Carlsson L (1992) Loads and designs dor screw joints for single crowns supported by osseointegrated implants. Int J Oral Maxillofac Implants 7(3): 353-359.

19. Jemt T (1991) Failures and complications in 391 consecutively inserted fixed prostheses supported by Branemark implants in edentulous jaws: a study of treatment from the time of prosthesis placement to the first annual checkup. Int J Oral Maxillofac Implants 6(3): 270-276.

20. Jorneus L, Jemt T, Carlsson L (1992) Loads and designs dor screw joints for single crowns supported by osseointegrated implants. Int J Oral Maxillofac Implants 7(3): 353-359.

21. Tzenakis GK, Nagy WW, Fournelle RA, Dhuru VB (2002) The effect of repeated torque and salivary contamination on the preload of slotted gold implant prosthetic screws. J Prosthet Dent 88(2): 183-191.

22. Binon PP (1996) The effect of implant abutment hexagon misfit on the screw joint stability. Int J Prosthodont 9(2): 149-160.

23. Drago CJ (2003) A clinical study of the efficacy of goldtite square abutment screws in cement-retained implant restorations. Int J Oral Maxillofac Implants 18(2): 273-278.

24. Dellinges MA, Tebrock OC (1993) A measurement of torque values obtained with hand held drivers in a simulated clinical setting. J Prosthodont 2(4): 212-214.

25. Finger IM, Castellon P, Block M, Elian N (2003) The evolution of external and internal implant/abutment connections. Pract Proced Aesthet Dent 15(8): 625-632.

26. Shetty M, Krishna Prasad D, Shetty NH, Jaiman R (2014) Implant abutment connection: Biomechanical Perspectives. NUJHS 4(2): 47-53.

27. McGlumphy EA, Mendel DA, Holloway JA (1998) Implant screw mechanics. Dent Clin North Am 42(1): 71-89.

28. Rangert B, Jemt T, Jorneus L (1989) Forces and moments on Branemark implants. Int J Oral Maxillofac Implants 4(3): 241-247.

29. AlJabari Y, Fournelle R, Ziebert G, Toth J, Iacopino A (2008) Mechanical behavior and failure analysis of prosthetic retaining screws after longterm use in vivo. Part 2: Metallurgical and micro hardness analysis. J Prosthodont 17(3): 181-191.

30. MartinWC, Woody RD, Miller BH, Miller AW (2001) Implant abutment screw rotations and preloads for four different screw materials and surfaces. J Prosthet Dent 86(1): 24-32.

31. AlJabari Y, Fournelle R, Ziebert G, Toth J, Iacopino AM (2008) Mechanical behavior and failure analysis of prosthetic retaining screws after long-term use in vivo. Part 1: Characterization of adhesive wear and structure of retaining screws. J Prosthodont 17(3): 168-180.

32. Quek E, Tan KB, Nicholls JI (2006) Load fatigue performance of a singletooth implant abutment system: effect of diameter. Int J Oral Maxillofac Implants 21(6): 929-936. 
33. Williams DN (1962) The hydrogen embrittlement of titanium alloys. J Inst Metals 91: 147-152.

This work is licensed under Creative Commons Attribution 4.0 License DOI: 10.19080/ADOH.2018.08.555741
34. Steves PJ, Frederickson EJ, Gress ML (2000) Implant Prosthodontics: Clinical and Laboratory Procedures ( $2^{\text {nd }}$ edn), St Louis, Mosby, Inc, USA, pp. 153-165.

\section{Your next submission with Juniper Publishers} will reach you the below assets

- Quality Editorial service

- Swift Peer Review

- Reprints availability

- E-prints Service

- Manuscript Podcast for convenient understanding

- Global attainment for your research

- Manuscript accessibility in different formats

( Pdf, E-pub, Full Text, Audio)

- Unceasing customer service

Track the below URL for one-step submission https://juniperpublishers.com/online-submission.php 